УДК 519.873

\title{
Probability-time Characteristics of GLONASS Navigation Signal Search
}

\author{
Vladimir A. Mironov* \\ Military educational scientific center air force "VVA" \\ Bolshevikov, 54a, Voronezh, 394064 \\ Russia \\ Valeriy N. Tyapkin ${ }^{\dagger}$ \\ Dmitry D. Dmitriev $\ddagger$ \\ Military Engineering Institute \\ Siberian Federal University \\ Svobodny, 79, Krasnoyarsk, 660041 \\ Russia \\ Alexey V. Korovin ${ }^{\S}$ \\ Military educational scientific center air force "VVA" \\ Bolshevikov, 54a, Voronezh, 394064 \\ Russia \\ Nikolay S. Kremez \\ Military Engineering Institute \\ Siberian Federal University \\ Svobodny, 79, Krasnoyarsk, 660041 \\ Russia
}

Received 30.01.2017, received in revised form 10.04.2017, accepted 20.07.2017

The article presents the results of calculations of probability-time characteristics of the signal in search of radio navigation equipment. Particular attention is paid to the calculation of the search time for given probabilities of correct detection and false alarm. The case of re-capturing the signal for tracking by radio navigation equipment after breaks due to antenna shading, interference effects, etc. is considered.

Keywords: radio navigation equipment, GLONASS, signal search, probability-time characteristics. DOI: 10.17516/1997-1397-2017-10-4-450-455.

\section{Introduction}

One of the most important parameters of modern radio navigation equipment (RNE) for global navigation satellite systems (GNSS) is the readiness time of navigation parameters. This time depends on the relevance of GNSS almanacs, visibility of satellite constellations, signal/ noise ratio of the received signals, the search algorithms implemented in hardware signals. The first

\footnotetext{
*mirvam@live.ru

$\dagger$ tyapkin58@mail.ru

$\ddagger$ dmitriev121074@mail.ru

§korovin.alexey@mail.ru

『nkremez@sfu-kras.ru

(c) Siberian Federal University. All rights reserved
} 
three causes are external and their effects cannot be eliminated directly in hardware. The fourth reason depends only on the features of the navigation receiver construction and the manufacturer can and should take measures to reduce the signal search time in the equipment. Below we shall carry out an assessment of probability-time characteristics of the signal in search of radio navigation equipment.

\section{Assessment of probability-time characteristics of the signal in search of radio navigation equipment}

In deriving the relations that allow us to estimate the probability-time characteristics of the signal, we use the following constraints and assumptions:

- the events, which are to take a decision on the presence the signal in each matrix cell research, are independent;

- the signal has an equal probability in any search matrix cell, i.e. the following formula holds

$$
\mathrm{W}_{1}=\frac{1}{N}
$$

In the receiving device of radio navigation equipment, the principle of multi-stage signal detection is based on the decision algorithm [1]. This principle is that in each cell of the search range, several detection stages are carried out, each of which is characterized by its analysis time and its threshold.

The analysis begins with the first stage. Each subsequent stage is carried out only if the threshold has been exceeded at the previous stage. If there has been no such excess, the analysis of this cell ends with the decision that there is no signal in it, and a transition to the next cell is made. The final decision about the presence of a signal in the cell is accepted in the event that the threshold has been exceeded at all stages of detection. At the first stage of detection, the analysis time is equal to a value of $T_{s}$ (single scan). Since, in practice, the probability of false alarm is chosen equal to $W_{F A}=10^{-3} \ldots 10^{-4}$, in the second stage of detection, the errors of the first stage are detected with a probability close to unity. This occurs at an analysis time of $m \cdot T_{s}$, where $\mathrm{m}$ is the number of times the unit cell is viewed $(\mathrm{m}=2,3,4, \ldots)$.

If a useful signal is detected at the first stage, the multi-stage detection algorithm will stop the search with a probability close to unity. Taking into account the constraints and assumptions adopted, we shall evaluate the relation between mean signal search time $t_{p s r}$ and the probability of correct detection $\left(W_{C D}\right)$ and false alarms $\left(W_{F A}\right)$. For this purpose, the analysis represents the average of one cell in the absence of a signal as the expected value of a discrete random variable that takes two values.

The first is equal to the time of analysis of the cell in the absence of error of the first kind $\left(T_{s}\right)$, and the second is equal to the analysis time in the event of an error of the first kind at the first viewing $(m \cdot T s)$. In this case, the average time for analyzing the cell in the absence of a signal in it can be represented in the form

$$
t_{m e d 1}=T_{s}\left(1-W_{F A}\right)+m \cdot T_{s} .
$$

If after scanning the entire search matrix the signal is not detected, then the scanning time is equal to

$$
t_{T}=N
$$


Table 1. Probabilistic-time description of the search procedure signal

\begin{tabular}{|l|c|c|}
\hline $\begin{array}{l}\text { The number of scans } \\
\text { search matrix }\end{array}$ & The probability of signal detection & Signal detection time \\
\hline 1 & $W_{C D}$ & $t_{1}=t_{\text {medT }}$ \\
\hline 2 & $\left(1-W_{C D}\right) W_{C D}$ & $t_{2}=t_{T}+t_{\text {medT }}=3 t_{\text {medT }}$ \\
\hline 3 & $\left(1-W_{C D}\right)^{2} W_{C D}$ & $t_{3}=2 t_{T}+t_{m e d T}=5 t_{\text {medT }}$ \\
\hline $\mathrm{n}$ & $\left(1-W_{C D}\right)^{n-1} W_{C D}$ & $t_{n}=(2 n-1) t_{m e d T}$ \\
\hline
\end{tabular}

If the signal is detected, the average search time of the search matrix is

$$
t_{m e d T}=\sum_{i=1}^{n_{\tau}} \sum_{j=1}^{n_{f}} i j t_{m e d 1} W_{1}=\frac{1}{2} N t_{m e d 1}
$$

where i, j are serial numbers of columns and rows of the search matrix, respectively. Taking into account the expressions (3) and (4), we shall describe the description of the signal search procedure. The results are shown in Tab. 1. The expected value of the average search time signal is equal to

$$
t_{\text {med }}=\sum_{n=1}^{\infty}(2 n-1) t_{\text {medT }}\left(1-W_{C D}\right)^{n-1} W_{C D}=\frac{2-W_{C D}}{W_{C D}} t_{m e d T} .
$$

Substituting expressions (2) and (4) in (5), we obtain the required value

$$
t_{\text {med }}=\frac{1}{2} \frac{\Delta T \sum \Delta F}{\tau_{\text {ref }} \cdot f_{\text {ref }}} T_{s}\left[1-(m-1) W_{F A}\right] \frac{2-W_{C D}}{W_{C D}},
$$

where $\tau_{r e f}, f_{\text {ref }}$ are symbol duration and carrier frequency. Another important characteristic of the search scheme is the probability that a signal $\left(W_{t}\right)$ will be detected within time t. This probability can be written as

$$
W_{t}=1-\left(1-W_{C D}\right)^{\left[t / t_{T}\right]}
$$

where $\left[t / t_{T}\right]$ is the integer part of the quotient. Thus, the expressions (6) and (7) fully describe the probability-time characteristics of the signal in search of radio navigation equipment.

The most interesting for further considerations is the case of signal re-capture by equipment after interruptions due to shadowing antennas, interference effects, etc. In this case, to obtain quantitative values of probability-time characteristics of the search pattern it is necessary to estimate the sizes of areas of uncertainty on the time $\left(\Delta T_{\sum}\right)$ and frequency $\left(\Delta F_{\sum}\right)$ of the position signal. The size of these areas depends on the input in the search pattern error apriori target designations (TD) to these provisions of the signal. The values obtained will allow us to further justify the threshold signal-to-noise ratios for the received signal.

The following errors are related to the factors influencing TD errors:

- prediction of the location of the spacecraft $\sigma_{s c}$;

- estimation of the consumer's location $\sigma_{n e}$;

- estimating the speed of the consumer $\sigma_{V n e}$;

- estimation of system time in consumer equipment $\sigma_{T n e}$;

- synchronization of spacecraft's signals with respect to the system time $\sigma_{T s c}$. 
We shall consider the effect of these factors on the size of the search area of the signal at the position on the scale time $\Delta T_{\sum}$. The root-mean-square deviation (RMSD) of TD errors (occurring due to the time position of the signal due to the error in the prediction of the position of the spacecraft $\sigma_{\tau_{1}}$ and due to errors in estimating the location of the consumer $\sigma_{\tau_{2}}$ ) are determined from the following expressions:

$$
\sigma_{\tau_{1}} \approx \tau_{s c} / c ; \quad \sigma_{\tau_{1}} \approx \tau_{n e} / c
$$

where $\mathrm{c}$ is the speed of light. RMSD of the error in TD estimate from the time position due to the error in estimating the system time in the radio navigation equipment $\sigma_{\tau_{3}}$ is determined from expression

$$
\sigma_{\tau_{3}}=\sigma_{\tau_{T n e}}=\gamma \Delta t_{N S},
$$

where $\gamma$ is relative instability of frequency generator of radio navigation equipment; $\Delta t_{N S}$ is the time interval during which the reception of signals was violated.

RMSD of TD error by the time position due to errors in the synchronization of spacecraft signals with respect to the system time $\left(\sigma_{\tau_{4}}\right)$ does not exceed $1 \mu \mathrm{s}$.

RMSD of the methodological error in calculating TD by the time position $\left(\sigma_{\tau_{5}}\right)$, caused by linear extrapolation of the user's trajectory, can be taken as $0.2 \mu s$ for the time of calculations.

The total RMSD of the error in the calculation of TD can be found on the assumption of independence and normal distribution of random factors. Then

$$
\sigma_{\Sigma \tau} \approx \sqrt{\sigma_{1}^{2}+\sigma_{2}^{2}+\sigma \tau_{3}^{2}+\sigma \tau_{4}^{2}+\sigma \tau_{5}^{2}}
$$

and the search zone by time position, respectively, will be equal to

$$
\Delta T_{\sum} \approx 6 \sigma_{\sum \tau}
$$

Let's consider the effect of the above factors on the size of the search area on the signal frequency position. RMSD of the error in calculating TD by frequency due to errors in the prediction of the location of spacecraft $\sigma_{f 1}$ is determined from expression

$$
\sigma_{f 1} \approx \frac{V_{r}}{\lambda H} \sigma_{s c}
$$

where $V_{r}$ is the radial velocity of the spacecraft with respect to the consumer; $\mathrm{H}$ is height of the spacecraft orbit; $\lambda$ is signal wavelength. RMSD in TD error by frequency due to inaccurate knowledge of their coordinates $\sigma_{f 2}$ are determined from expression

$$
\sigma_{f 2} \approx \frac{V_{r}}{\lambda H} \sigma_{n e}
$$

RMSD error of targeting the frequency due to inaccurate estimation of consumer speed $\left(\sigma_{f 3}\right)$ for the spacecraft, located at the zenith, at an inclination to the horizontal trajectory of the consumer $\alpha$ is determined by the expression

$$
\sigma_{f 3} \approx \frac{\sigma_{V n e} \sin \alpha}{\lambda}
$$

RMSD errors in calculating TD by frequency $\sigma_{f 4}$, caused by an unknown difference in the actual and nominal value of the frequency of the consumer's generator, is determined from expression

$$
\begin{gathered}
\sigma_{f 4} \approx f_{c} \gamma, \\
-453-
\end{gathered}
$$


where $f_{c}$ is the frequency of the carrier signal.

RMSD of the methodical error TD by frequency can be taken equal to $60 \mathrm{~Hz}$. The total RMSD error in calculating TD by frequency will be

$$
\sigma_{\Sigma f} \approx \sqrt{\sigma_{f 1}^{2}+\sigma_{f 2}^{2}+\sigma_{f 3}^{2}+\sigma_{f 4}^{2}+\sigma_{f 5}^{2}}
$$

and, respectively $\Delta F_{\Sigma} \approx \sigma_{\Sigma f}$. Let us consider the probability-time characteristics of the signal in search of radio navigation equipment. Signal search will be carried out in case when the sizes of the signal search zones by the time and frequency positions exceed the maximum allowed values. This can be caused by the following reasons:

- long-term presence of radio navigation equipment in the area affected by interference;

- prolonged shading spacecraft signals;

- use on the customer of a reference generator with considerable frequency instability $(\gamma=$ $\left.10^{-6} \ldots 5-10^{-7}\right)$.

In calculating the probability-time characteristics of the signal search, the original data was used [1]. The effective spectral width of the signal is $\Delta f_{c}=1 \cdot 10^{7} \mathrm{~Hz}$ for the P-code signal and $\Delta f_{c}=1 \cdot 10^{6} \mathrm{~Hz}$ for the $\mathrm{C} / \mathrm{A}$-code signal. In radio navigation equipment quartz oscillators with frequency instability with the order of $\gamma=10^{-7} \ldots 10^{-8}$ are used as frequency stabilizers. RMSD position errors by the consumer $\sigma_{n e}$ depends on the time interval in the measurement of navigation parameters $\Delta t_{N S}$. When predicting the coordinates of the spacecraft from the data of the almanac, the RMSD error errors in estimating the position of the spacecraft reach $20 \mathrm{~km}$. The height of the circular orbit of the spacecraft is $\mathrm{H}=20000 \mathrm{~km}$. The average radial velocity of the spacecraft relative to the consumer $V_{R} \approx 500 \mathrm{~m} / \mathrm{s}$. The signal wave length is $\lambda=19 \mathrm{~cm}$.

RMSD errors in measuring the speed of the consumer $\sigma_{V p} \approx 5 \mathrm{~km} / \mathrm{h}$. The angle of the trajectory of the consumer to the horizon for the sample calculation is $\alpha=30^{\circ}$. The number of views in the second detection stage is minimal, i.e. $\mathrm{m}=3$.

\section{Conclusion}

From the results of calculations for the above initial data it follows that:

- at a signal / noise ratio of less than $34 \mathrm{~dB}$, the GPS signal search becomes impossible (the probability of signal capture during the search time of 5 minutes will be $0.05 \ldots 0.14$ );

- for GLONASS, the signal search scheme is operational with a signal-to-noise ratio of at least $37 \mathrm{~dB}$.

The probability-time characteristics of the navigation signal search can be significantly improved by increasing the accuracy of the a priori information about the location of the consumer and the system time.

The research was financed by the Ministry of Education and Science of the Russian Federation (agreement no. 14.578.21.0116, unique project RFMEFI57815X0116).

\section{References}

[1] A.I.Perov, V.N.Kharisov, GLONASS. Principles of construction and operation, Moscow, Radio, 4th ed., revised, 2010 (in Russian). 


\title{
Вероятностно-временные характеристики поиска навигационного сигнала ГЛОНАСС
}

Владимир А. Миронов

Военный учебно-научный центр Военно-воздушных сил ВВА

Старых Большевиков, 54аб, Воронеж, 394064

$$
\text { Россия }
$$

Валерий Н. Тяпкин

Дмитрий Д. Дмитриев

Военно-инженерный институт

Сибирский федеральный университет Академгородок, 13А, корпус 8, Красноярск, 660036

Россия

Алексей В. Коровин

Военный учебно-научный центр Военно-воздушных сил ВВА

Старых Большевиков, 54аб, Воронеж, 394064

Россия

Николай С. Кремез

Военно-инженерный институт

Сибирский федеральный университет

Академгородок, 13А, корпус 8, Красноярск, 660036

Россия

\begin{abstract}
В статье приведены результаты расчетов вероятностно-временных характеристик поиска сигнала в навигационной аппаратуре потребителя. Особое внимание уделено расчету времени поиска при заданных вероятностях правильного обнаружения и ложной тревоги. Рассмотрен случай повторного захвата сигнала на сопровождение навигационной аппаратурой потребителей после перерывов в результате затенения антенн, воздействия помех и т.n.
\end{abstract}

Ключевые слова: навигачионная аппаратура потребителей, ГЛОНАСС, поиск сигнала, вероятностно-временные характеристики. 